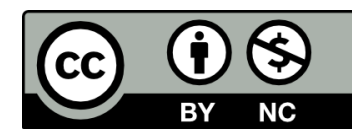

\section{Montessori Literature Through the Lens of Leadership}

Karen Bennetts and Jane Bone, Monash University, Australia

Keywords: Montessori, leadership

Abstract: This article reviews the Montessori literature through the lens of leadership, using Maria Montessori's writings for a perspective on leadership aligned with her principles and practices. Dr. Montessori was a strong leader who argued that adults, as leaders, should take direction from children as the spiritual builders of human beings. Her concept of the prepared environment, including the prepared adult, supports this foundation for leadership and has applications beyond the classroom context. Leadership in the Montessori context has a biological base but incorporates elements of service and morality that guide social reform with a peaceful telos. While there are overlaps with existing models of leadership, this review suggests that a distinct perspective on leadership does begin to emerge from Dr. Montessori's legacy.

Adair (1989) traced the etymology of leadership to the Anglo-Saxon root laed, a path or road, and laeden, a verb meaning to travel or go. Leadership is defined as "the action of leading a group of people or an organisation, or the ability to do this" (Oxford University Press, n.d.). Political scientist James MacGregor Burns, who wrote a seminal text in the leadership field, added the concept of values: "I define leadership as leaders inducing followers to act for certain goals that represent the values and the motivations - the wants and needs, the aspirations and expectations - of both leaders and followers" (Burns, 1978, p. 19).

The leadership literature is large and diverse, but a review found few research studies addressing leadership in the Montessori context and almost no publications that could be considered to make substantial links between leadership and Montessori principles and practices. Maria Montessori does not appear to have status as a leadership theorist, remaining classified as a pedagogue, much of whose innovation has been included in contemporary practice without reference to its origins (Feez, 2010; Mooney, 2000). In this review, to allow Dr. Montessori's perspective on leadership to emerge, inferences have been drawn from her original writings.

Dr. Montessori's specific references to leadership appear fragmentary, subtle, or indirect. She did not set out to write specifically about leading, and the term leadership was not as commonly used in her day. Dr. Montessori's publications are sprinkled with references to leaders within scientific and social fields. For example, she referred to the Czech philosopher and pedagogue, Comenius, in From Childhood to Adolescence (M. Montessori, 1948/1994), the contributions of many ancient Greek leaders in To Educate the Human Potential (M. Montessori, 1948/1989b), and the legacies of Darwin and De Vries in her chapter on embryology 
in The Absorbent Mind (M. Montessori, 1949/2007a).

Her own leadership can be traced through various biographical works (Babini, 2000; Foschi, 2008; Kramer, 1988; Standing, 1957/1998; Trabalzini, 2011). She was a pioneer of women's rights, but Kramer (1988) reported that Dr. Montessori made the most of her personality to champion the cause of children. Margaret Naumberg, one of Dr. Montessori's early students, described her arrival in the United States in 1913, where she was greeted as a distinguished visitor, was the guest of Alexander Graham Bell, and was received in a special audience by President Woodrow Wilson: "Montessori is in America now. Three years ago no one over here even knew of her existence. Today they use her name as a leader" (Naumberg, 1913, p. 796).

Naumberg has described the charisma that was an aspect of Dr. Montessori's leadership:

She can seize an audience and sweep it with her by the sheer drawing power of her personality. She is one of those rare people who can at times speak and give themselves to an audience without reserve. As she talks she intuitively expresses every thought with the slightest movement of her body. Her voice becomes vibrant, her eyes luminous, a general radiance suffuses her form, and the words break from her lips aglow. (Naumberg, 1913, p. 799)

The words of one of her biographers support this view:

... the effect she always had on peers and pupils, strangers who became her devoted followers, listeners who came to hear her and with striking frequency spoke of being "converted," "enlightened," of having their way of seeing things - sometimes their entire lives — changed by her presence. It was not just her message... She had the kind of personality that invites identification. (Kramer, 1988, p. 114)

Dr. Montessori's grandson, Mario M. Montessori, wrote that she maintained her vitality and personal magnetism up until her death (M. M. Montessori, 1992). Standing (1957/1998) claimed that in private she was more diffident, and this is supported by her statement reflecting the humility of her leadership:
Further I protest against myself being hailed as the great educator of this century, because what I have done is merely to study the child, to take and express what he has given me, and that is called the Montessori Method. At the most I have been the child's interpreter. (M. Montessori, 1946/1989a, p. 4)

Dr. Montessori's legacy was informed by a rich intellectual heritage: Italian mentors in her early work in science, medicine, and anthropology; French doctors Jean Marc Gaspard Itard and Édouard Séguin, who initially inspired her pedagogical direction; philosophical study in humanism, ancient Greek philosophy, and German classicism; and her experiences in India from 1939 to 1946, where she was exposed to Eastern traditions. Yet by placing the child at the center of all human endeavor, her view seems to challenge contemporary leadership perspectives. Her body of work addresses broad social themes of human development and peace, as well as ontological universalities and contextualities. Dr. Montessori viewed education as broad and lifelong - not merely a transmission of culture but a help to life in all its expressions. In the classroom, this help is overseen by an educational leader, called a directress in her day ( $M$. Montessori, 1912/1964), who engages in leadership by taking direction from the child.

\section{Leadership Literature Review}

The literature outlines a variety of different leadership theories and styles whose relevance depends on the context in which it is applied (Ahmed et al., 2016). Burns (1978) initially cemented the leadership field's progress beyond a focus on the individual traits and psychology of the leader, leading to decades of work on transformational leadership. Transformation became the leadership approach of choice for researchers and practitioners, becoming associated with higher levels of performance and behaviors (Bass \& Riggio, 2006). Heifetz (2009) argued for a less grandiose conception of leadership, preferring an orientation that addresses the dailiness of the work. He drew from evolution theory to develop an adaptive leadership theory. Conger (1989) investigated charismatic leadership, which emerged from corporate work in the 1980s and emphasized entrepreneurial leaders with charm, heroism, and skilled self-marketing. In contrast, Greenleaf (1977) began to shift the focus 
toward servant leadership. This paradoxical model argues the effective leader is humble, going beyond self-interest to serve without expecting to be served. The leader is a servant first and leader second. Servant leadership has a reciprocal relationship between leader and follower that invokes a mutually upward spiral (van Dierendonck, 2010).

For some time, leadership has been considered through a range of lenses, including gender and feminist perspectives (Blackmore, 2013; Rhode, 2003) and crosscultural perspectives, particularly from non-Western models, though these models are acknowledged as diverse (Arvey et al., 2015; Derungs, 2011). Contextual approaches, such as religious leadership (Callahan, 2013), are becoming well represented, and youth leadership is an emerging strand (Dempster et al., 2013; Gould \& Voelker, 2012). Giacalone and Jurkiewicz (2010) wrote of a burgeoning scientific interest in the role of spirituality as the search for meaning extends from the personal to the professional arena. Van Dierendonck (2010) stated that spiritual leadership overlaps with servant leadership, but the latter has avoided much confusion by being entirely secular. Spirituality has begun to be linked to indigenous leadership (Julien et al., 2010), but more studies appear needed to develop this thread. Gronn's (2010) genealogy revealed that the issues that preoccupy leaders are of a timeless and enduring nature. Yet others lament the lack of philosophical depth, critical ethos, and analysis of major global crises in terms of leadership from leadership researchers more concerned with journal rankings (Tourish, 2015).

Thinking about the limitations of previous research and the need for authentic leadership in Montessori settings induced me to revisit Dr. Montessori's original ideas. From the beginning, she was writing in terms of leadership concepts from the literature, including transformation, adaptation, service, humility, contextual elements, and spirituality (M. Montessori, 1912/1964). She also acknowledged the importance of charisma, insisting her teachers "attract," "be seductive" and "entice the children" to activity (M. Montessori, 1949/2007a, p. 253). How might Dr. Montessori's publications provide direction for leaders today?

\section{Montessori Philosophy}

Tornar's (2001) significant bibliography described the editions, reprints, and translations of Montessori texts over the years. Dr. Montessori's early graduate writing in medicine was a foundation for The Montessori Method, published in 1912, and subsequently considered the birth certificate of Montessori pedagogy (Trabalzini, 2011). Most of Dr. Montessori's more mature publications are based on lecture notes compiled by others. These later works are the fruits of a lifetime's research and study and are characteristically broader. In these, Dr. Montessori considers education over wider stages of life; refers to developing sciences such as psychology, embryology, and ecology; locates the achievement of global peace firmly within the field of education; and describes contemporary social problems and the child's contribution to world reconstruction.

Dr. Montessori wrote and lectured mostly in Italian and scholars have documented issues with translation of her work (Feez, 2007; Kramer, 1988). Lloyd (2008) claimed that Dr. Montessori's theoretical perspective is not readily available in published literature, though an understanding of Montessori terminology is central to fully appreciate her legacy. Feez (2007) confirmed that Dr. Montessori did not outline her key principles with clarity, and trawling through the mix of anecdotes, philosophy, opinion, and loosely described theoretical positions in her books is required to fully grasp the nuances. Authors have attempted to contain and elucidate Montessori principles and practices over the decades. Haines's (2001) glossary of Dr. Montessori's key terms explained some central ideas that relate to the education of children of 3 to 6 years of age.

Lillard (2005) outlined eight principles and several practices that reflect differences in the setup, schedule, and curriculum of a Montessori classroom compared with a traditional classroom. Schmidt and Schmidt (2009) listed 18 Montessori principles and 19 teaching techniques used to implement those principles. Other writers have discussed key Montessori concepts using contemporary or simplified terminology (Feez, 2010; Helfrich, 2011; O’Donnell, 2013). Feez (2007) emphasized that Dr. Montessori did outline a complex and sophisticated theory of practice in each of her principles, and these principles should not be oversimplified. Cossentino (2009) argued that many aspects of Dr. Montessori's legacy are paradoxical, such as the emphasis on freedom while also valuing order and limits. Cossentino believed paradoxes define the vitality of the Montessori approach, but they have been confounding and have limited the study of Montessori 
education by scholars and policymakers. In this sense, the literature offers an open field for exploration, interpretation, and connection to other pedagogies and wider disciplines.

\section{A Biological Base}

One of Dr. Montessori's biographers wrote, "So often, we find an underlying affinity between Montessori's system and biology. Indeed it is true to say that her whole system - in theory and practice-has a biological foundation" (Standing, 1957/1998, p. 118).

We have a much greater understanding of biology today than in her time, but Dr. Montessori's notions of the interdependence of organisms remains relevant. Standing (1957/1998) claimed that her research methodology was, in essence, the same as that of biologists observing the spontaneous activity of free organisms. Like the biologist, she was interested in both the organism and its integration within a living system.

In giving an account of the Montessori system it is difficult to know where to begin, because it is hard to single out one principle as more important than the others. In an organism all organs are essential, for each plays a necessary part in the whole. And so it is in the Montessori system, and for much the same reason; because it is a living system. It displays that multiplicity in unity which is characteristic of all organisms. (Standing, 1957/1998, p. 105)

Dr. Montessori perceived children as the constructors of adults, powered by inborn vital energies, writing "The origins of the development, both in the species and in the individual, lie within" (M. Montessori, 1912/1964, p. 105). She argued that there were universal human tendencies, such as to orient, to order, to explore, to communicate, to create, and to abstract, and these operated throughout each person's lifespan. Yet she claimed there were other constructive powers, such as the young child's absorbent mind and sensitive periods, which were time limited within a continuum of developmental stages (M. Montessori, 1946/1989a, 1949/2007a).

Dr. Montessori drew attention to "the significant unity of method in all natural building," which can be considered for life at any scale, "for atom as for planet" (M. Montessori, 1948/1989b, p. 76). She saw that this method included the freedom and independence of organs, the development of cell specialization, the unification of organs by the circulatory system, and directive communication through the nervous system.

The alignment of human development and activity with biological principles offers the first clues toward a Montessori perspective on leadership. For Dr. Montessori, the human organism was a vibrant, integrated, and coherent community that is governed by specially prepared internal leadership:

The nervous cells specialize in refinement, and one cannot conceive of one of them taking upon itself to turn starch into sugar, or fight a microbe. They imprison themselves in a closed box, the cranium, and it is not by any general election that they get their place in the governing body. The embryo can teach us the absurdity of our social mechanism, where one group claims to dominate another merely by authority, without agreement. Nature is the teacher of life-let us follow her ways! (M. Montessori, 1948/1989b, p. 77)

Dr. Montessori foresaw increasing globalization, not yet fully recognized in her own time, as an inevitable stage in the life of humanity, which had become "a single organism, one nation” (M. Montessori, 1992, p. 25). She envisioned a circulatory system within social life, whereby products from different peoples moved through the system, and everyone took what they needed for their lives:

In recent years, we can even see the growth of arrangements doing the work of hormones. These are the efforts of large states to plan the environment, to control commerce, stimulate, encourage, and direct the undertakings of all nations, simply with a view to achieving greater harmony and well-being of all. One may say that the defects that have shown themselves clearly enough in these attempts merely prove that the embryonic development of the social circulatory system, though it has made a beginning, is still far from perfect. (M. Montessori, 1949/2007a, p. 40)

Dr. Montessori continually repeated her call for human systems to be inspired by and take direction from nature's patterns: 
As for the specialised cells of the nervous system, anything corresponding to these is still woefully lacking in human society.... We have nothing that acts simultaneously on the whole social body, and guides it to harmony. Democracy, which is our civilisation's highest form of government, permits everyone to vote, and so to choose the Head of Affairs. For this to happen in embryology would be absurd beyond belief, for if each cell has to be specialised, then the cell able to direct all the others must be even more specialised. (M. Montessori, 1949/2007a, p. 40)

She continued:

Whoever directs others must have transformed himself. No one can ever be a leader or a guide who has not been prepared for that work. This principle, which links specialisation with function may well engage our active attention - all the more so as it seems to be nature's way. (M. Montessori, 1949/2007a, p. 41)

These passages suggest Dr. Montessori considered leadership at different social levels, though the writing does not allow us to clarify her perspective easily. However, we can infer from her ideas about human nature that she believed leadership required some maturity, but that potential for leadership work lay within each person, flourishing under a preparation that was transformational.

\section{Training as Preparation for Leadership}

The notion of training is an interesting counterpoint to the term education, often used in conventional teacher-preparation programs today. Dr. Montessori saw education as an aid to life, "not something which the teacher does, but... a natural process which develops spontaneously in the human being" (M. Montessori, 1949/2007a, p. 3). A respected contemporary Montessori leader argued that Montessori teacher training can be considered a psychological and spiritual preparation for leading a community of children that supports this natural process:

Montessori training has excelled in many areas. It has made every effort to convey a spirit of pedagogy so that the teacher is not merely an imitator of Montessori styles, but a thinking teacher, one who is on a certain mental quest.... If duration of the training permits, Montessori expertise becomes more than the knowledge of a curriculum; it is participation in a way of life, where the soul of learning is rooted in the development of the child. (Kahn, 1981, p. 2)

Leadership within this way of life is enacted through the goal of supporting the free, independent development of the human personality. The child does not exist merely to grow up but also has the task of constructing a unique personality (M. Montessori, 1949/2007a). The Montessori teacher is trained to entice the child to work and can offer a distinct application of charisma to support the constructive process. Dr. Montessori stated that "the essential thing is for the task to arouse such an interest that it engages the child's whole personality" (M. Montessori, 1949/2007a, p. 188).

The Montessori teacher's charisma is used just enough to invoke the child's concentration. Dr. Montessori believed that people are the authors of their own skills and that their different destinations can never be predicted (M. Montessori, 1949/2007a). She advocated an education based on natural, universal characteristics and tendencies, with freedom, opportunity for individual work, concentration, and repetition. When the environment is designed to foster these aspects of the child's work, the child undergoes a transformative process that Dr. Montessori referred to as normalization. She considered normalization a universal and observable phenomenon that is the child's contribution to society (M. Montessori, 1949/2007a). This contribution led her to believe that the child is the source of human regeneration, and she called upon world leaders to follow the child when considering human problems. She ended a speech to the World Fellowship of Faiths in London in 1939 with a clear image of the child as the leader of men: "We see the figure of the child who stands before us with his arms held open, beckoning humanity to follow" (M. Montessori, 1992, p. 119).

Dr. Montessori linked leadership and followership again in speaking to her students in 1942: "Anyone who wants to follow my method must understand that he should not honour me, but follow the child as his leader" (M. Montessori, 1970, p. 7).

These child-focused words challenge traditional, hierarchically focused notions of leadership often evident in education but also connect Dr. Montessori's ideas to developmental approaches and to models with inherent 
quietness and humility, such as servant leadership and spiritual leadership.

\section{The Teacher as Servant Leader: A Prepared Adult}

Arguing that development cannot be taught (M. Montessori, 1949/2007a), Dr. Montessori prepared her teachers to lead with the attitude of the scientist. This attitude defines a spiritual training in which one becomes a worshipper of nature:

The thing which we should cultivate in our teachers is more the spirit than the mechanical skill of the scientist.... We wish to direct the teacher, trying to awaken in him, in connection with his own particular field, the school, that scientific spirit which opens the door for him to broader and bigger possibilities. In other words, we wish to awaken in the mind and heart of the educator an interest in natural phenomena to such an extent that, loving nature, he shall understand the anxious and expectant attitude of one who has prepared an experiment and who awaits a revelation from it. (M. Montessori, 1912/1964, p. 9)

Yet the Montessori teacher is an active leader, not restricted to observation. The teacher's leadership, which is an element of the environment, suggests the stewardship of a self-organizing, self-actualizing ecosystem. Dr. Montessori did not use the term ecosystem, but sprinkled throughout her writings are references to concepts such as community, organisms, interconnection, cycles, energy, internal and external processes, function, adaptation, renewal, potentialities, equilibrium, and natural laws and processes (M. Montessori, 1949/2007a). She advocated considering classroom inputs carefully, studying the relationship between elements in the environment, setting limits, nurturing self-balancing processes, and analyzing outputs to determine what was needed next. The Montessori classroom is inherently sustainable, and obstacles to individual independence and to the interdependent harmony of the overall system are diminished or removed (M. Montessori, 1949/2007a). The teacher's personal preparation must be a complete selftransformation, so that the teacher does not become the obstacle: "Every useless help given to the child becomes an obstacle to his development. This is not merely philosophy but a fact to which we attach fundamental importance" (M. Montessori, 1994/2004, p. 15).
Dr. Montessori therefore recommended that each teacher make a deep preparation beneath the external pedagogical veneer to model moral leadership and "acquire a moral alertness which has not hitherto been demanded by any other system" (M. Montessori, $1948 / 1967$, p. 151). Dr. Montessori wrote that this alertness was revealed in the teacher's tranquility, patience, charity, and humility. "Not words but virtues" (M. Montessori, 1948/1967, p. 151) are the teacher's main qualifications.

The degree to which these concepts are bound to time and culture can be debated, but recent philosophical research has shown Dr. Montessori's thought can enrich contemporary virtue epistemology (Frierson, 2015). Paradoxically, leaders in a Montessori context are both assistants and servants of the human spirit, a reversal of roles relative to conventional education:

We teachers can only help the work going on, as servants wait upon a master. We then become witness to the development of the human soul; the emergence of the New Man, who will no longer be the victim of events, but thanks to his clarity of vision, will become able to direct and to mould the future of mankind. (M. Montessori, $1949 / 2007$ a, p. 8)

Here Dr. Montessori spoke about the teacher's role in preparing future leaders. Yet not all those she trained were destined for an educational career. Over her lifetime, she did not limit her training only to teachers but rather spoke to all adults with the same conviction: "The child is our teacher. Adults must above all be educated to acknowledge this fact so that they may change their behaviour toward the generations that come after them" (M. Montessori, 1992, p. 37).

Dr. Montessori reinforced the significance of humility and service as key pedagogical principles guiding the preparation of the adult who is led by children. In the Montessori approach, this paradoxical view of leadership is situated within the prepared environment.

\section{The Prepared Environment as a Foundation for Child- Led Activity}

Dr. Montessori claimed that the primary factor in developing human individuality was the power of natural, universal, inner forces. However, she saw the environment as influential, arguing that an appropriate environment 
was required for optimal human development based on these inner forces: "Environment is undoubtedly a secondary factor in the phenomena of life; it can modify in that it can help or hinder, but it can never create" (M. Montessori, 1912/1964, p. 105).

Nevertheless, the Montessori teacher addresses the needs of children indirectly by enacting leadership as the custodian of an enticing environment that functions as a world of progressive interest. The reciprocal, transformative relationship of people and their environments is a central Montessori tenet. The child's particular form of psychology shapes an unfolding selfconstruction:

Adults admire their environment; they can remember it and think about it; but the child absorbs it. The things he sees are not just remembered; they form part of his soul. He incarnates in himself all in the world about him that his eyes see and his ears hear. In us the same things produce no change, but the child is transformed by them. This vital kind of memory ... absorbs images into the individual's very life.... (M. Montessori, 1949/2007a, p. 56)

Dr. Montessori understood the child's creative powers for self-construction included the capacity to adapt to different cultures through environmental interaction. This drew her to focus the teacher's attention on the environment as the child's true teacher. Montessori environments are consequently prepared. An element of the prepared environment is the set of didactic materials, the prime purpose of which is to develop the child's energies. Dr. Montessori argued that the materials not only render self-education possible, but also provoke it (M. Montessori, 1912/1964). Her selection of objects emerged from observation. She found children were attracted to real, purposeful materials with beauty, simplicity, and order, and that it was best if these materials were durable, child sized, and accessible at low height. In maintaining the environment, the teacher becomes a servant leader, checking daily that everything is clean, tidy, and attractive to the children. The materials are limited in number but offer unlimited possibilities for exploration. Each environment is a reflection of the adaptive leadership of the teacher. Montessori principles are applied in keeping with the specific needs of the unique group of children within the classroom. The prepared environment offers all the essentials for the optimal development of each child but nothing superfluous. Materials support independence by isolating difficulties and having inbuilt control of error, simultaneously guiding, stimulating, and liberating the individual child (Bone, 2019). The principle of giving just enough help, which also relates directly to the leadership of the teacher, is paramount. An error

may be committed by an excessive quantity of educative material: this may dissipate the attention, render the exercises with the objects mechanical, and cause the child to pass by his psychological moment of ascent without perceiving it and seizing it. Moreover, such objects are then futile, and by their futility, "the child may lose his soul." (M. Montessori, 1918/1991, p. 61)

Here Dr. Montessori emphasized the spiritual connection of the child to the environment and the custodial servant leadership responsibilities exercised by the teacher. The relationship of the teacher's leadership to the development of children's spirituality within the prepared environment is discussed in more detail in Bennetts and Bone (2019). Dr. Montessori drew parallels between the child burdened by an excess of materials and an overindulgent adult, who was weakened and undisciplined: "If someone does not help him by wresting from him the futile objects, and pointing out his heaven to him, he will hardly have the energy to save himself" (M. Montessori, 1918/1991, p. 62).

Dr. Montessori considered adults who have saved themselves to be spiritual leaders:

A few men have "rescued" themselves from the shipwreck of humanity and lived simple, active lives - the lives, in fact, of children. These men, who have won their own salvation, whom we call saints, have given the world proof of a love capable of benefiting all mankind. (M. Montessori, 1992, p. 58)

Dr. Montessori viewed her didactic material as a spiritual staircase that brought forth the child's perseverance and joy, characteristic of the spirit when the internal energies have found their keyboard (M. Montessori, 1918/1991). The fixing of the child's attention on an activity manifests as equilibrium, serenity, and self-control. Yet for Dr. Montessori, materials was a 
conceptualization not limited to a concrete form. Older children gradually move away from manipulatives, working in the abstract. Adolescents continue selfeducation through their connection with the land and their affinity with elders in the environment, who may operate as didactic materials (Kahn, 2005). Dr. Montessori does not appear to have specifically elaborated what materials might provoke self-education of the mature adult. Through the legacy of her literature, however, as part of her own preparation for leadership, she modeled observation of nature, as well as reading and reflection on well-credentialed work from a wide range of scientific and philosophical disciplines.

\section{The Child as an Emerging Leader in the Community}

Kahn (2005) suggested that Dr. Montessori's fame as an educationalist obscures her contribution as a social philosopher. She grappled with large questions, and, from the beginning, her writings addressed themes of liberty, responsibility, morality, spirituality, consciousness, the family, work, and society (M. Montessori, 1912/1964). Montessori classrooms are a mixed-age minisociety, and socialization unfolds naturally in response to shared interests, rather than an imposed, age-delineated structure. The needs of the group frame the limits to individual freedom, and the teacher models decisionmaking with grace and courtesy. Dr. Montessori stated that moral principles could not be given by teaching but by prolonged social experience in keeping with the child's developmental stage:

Little children go along harmoniously by themselves, but junior-age children need a leader to rule and command. They need another kind of organisation.... We can compare the two forms to a piece of weaving. When a piece of cloth is to be woven, the warp is prepared first. All the threads lie close together, but parallel to each other. This is like the society by cohesion. They are all fixed at one point, but they do not intermingle. The second stage is when the shuttle attaches all the threads together. This is like the work of the leader who connects all the people together. (M. Montessori, 2012, p. 138)

Dr. Montessori believed that after the age of 6 , the child associates the self with others, not merely for the sake of company but also for social organization: "He likes to mix with others in a group wherein each has a different status. A leader is chosen, and is obeyed, and a strong group is formed. This is a natural tendency, through which mankind becomes organised" (M. Montessori, 1948/1989b, p. 4).

Dr. Montessori believed the connection to the leader comprised moral elements:

Civilisation is to be judged not only by its outer appearance, but also by its moral standards. Nomads ... required ... great discipline, order and bravery, endurance of cold, heat, lack of food and water, and a special tribe loyalty and devotion to a leader. (M. Montessori, 1948/1989b, p. 49)

In the post-WWII climate, Dr. Montessori was highly sensitive to such devotion, considering obedience in its relationship to self-control and the will.

Obedience is no mechanical thing, but a natural force of social cohesion, intimately related to the will, even its sublimation.... Obedience of the right kind is a sublimation of the individual's will, a quality in the human soul without which society could not exist. But an obedience without true self-control, an obedience which is not the consequence of an awakened and exercised will, brings whole nations to disaster. (M. Montessori, 1948/1989b, p. 84)

Dr. Montessori noted that great achievers experience an earlier period of intense effort toward a goal, not necessarily on the same lines as the final work. This effort orients the spirit and is an indirect preparation.

So indirect preparation was adopted as an integral part of the Montessori Method. We had seen that nature prepares indirectly in the embryo; she issues no orders until the organs have been prepared for obedience. Character, can be built only in the same way. (M. Montessori, 1946/1989a, p. 56).

The importance of this inner work convinced Dr. Montessori that the child was the origin and the transforming and uniting element of society.

So we get an insight into the natural course of social embryology. It is usual to regard society as based on government and laws; the children reveal that there must first be individuals of developed will, and then a call which brings them together preceding organisation. 
First strength of will is needed, then cohesion by sentiment, and last cohesion by will. (M. Montessori, 1946/1989a, p. 66)

Dr. Montessori offers clues to the value she gave to experience in society as a prerequisite for leadership.

The social experience begun earlier must be continued, because the person who has never worked, who has never tried to make his own living, who has never mingled with people of different age and of different social classes, will with difficulty become worthy of becoming the leader of anything. (M. Montessori, 1948/1994, p. 91)

Here Dr. Montessori speaks of the relationship between leadership, worthiness, diversity, and independence. She saw independence as a basic outcome of education and closely linked to freedom. Independence shapes the teacher's service into a lofty activity that supports self-mastery and dignity, without sinking to the actions of a traditional servant: "In reality, he who is served is limited in his independence. This concept will be the foundation of the dignity of the man of the future; 'I do not wish to be served, because I am not an impotent'” (M. Montessori, 1912/1964, p. 97).

The notions of freedom and independence as precursors to interdependence connect back to nature's plan as Dr. Montessori perceived it.

The man who, through his own efforts, is able to perform all the actions necessary for his comfort and development in life, conquers himself, and in doing so, multiplies his abilities and perfects himself as an individual. We must make of the future generation, powerful men, and by that we mean men who are independent and free. (M. Montessori, 1912/1964, p. 101)

Dr. Montessori saw the basic social problem as "human development in its totality; once this [result] is achieved in any unit - child or nation - everything else follows spontaneously and harmoniously" (M. Montessori, 1948/1989b, p. 9).

Dr. Montessori clarified that the core of social problems, from small to large scale, lies in the development of the individual human being. This is a lifelong unity of conception that seems missing from the leadership literature, which continues to emphasize leadership in the adult.

\section{Leadership for Social Reform and a Peaceful Telos}

Dr. Montessori's culturally coherent, if paradoxical, metanarrative invokes a peaceful telos, or ultimate aim, of human progress.

All humanity that works for the common good, even though it may be unaware of it, is creating the new world that must be the world of peace. The great efforts of men who have laboured, made discoveries, studied and suffered - all the work of mankind will be seen to have had one common purpose in the world that will be the word of peace. (M. Montessori, 1949/1992, p. 115)

Dr. Montessori returned to children and education to demonstrate the pathway to peace.

World-shaking forces are now making the realisation of human unity an urgent necessity. The time is past when some racial groups or nations can be civilised, leaving others servile or barbaric. Persistence in these outworn ideas can lead only to further wars and selfdestruction, and how can a general change of thought be effected but by the teacher, not as tyrant or missionary, but as essential leader of the rising generation? (M. Montessori, 1948/1989b, p. 77)

Decades after Dr. Montessori's call to action, the evolution of integrated systems to support human development, across its various stages, progresses slowly. The potential of the child as a guide that adult leaders can follow seems misunderstood or missing in our actions, reinforcing the child's status as a "forgotten citizen" (M. Montessori, 1949/1992, p. 38). The Montessori teacher exemplifies a perspective on leadership aligned with Montessori principles and practices. The teacher's authority to lead the classroom community emerges from teaching credentials and a formal appointment, yet Dr. Montessori wrote, "It is responsibility that a leader should feel, not the authority of his position" (M. Montessori, 1989a, p. 65).

This is a moral responsibility within a broad social mission, making leadership in the Montessori context distinct. Such a mission is embraced through a focus on each human being as a unity: "There exists only one real biological manifestation: the living individual; and toward single individuals, one by one observed, education must direct itself” (M. Montessori, 1912/1964, p. 104). 
Herein lies a great, self-balancing Montessori paradox that a strong, peaceful, and cohesive community constructs itself from a base of individual development.

\section{Conclusion}

Dr. Montessori covered a biologically based terrain of practices, values, and morality, yet to be fully illuminated for researchers, but which articulated her vision of the child as both a "hope and a promise for mankind" (M. Montessori, 1949/1992 p. 31). Her own leadership and her vision of the teacher as a classroom community leader have affinity with existing leadership concepts such as charisma, transformation, adaptation, service, humility, contextual elements, and spirituality. This affinity invites Montessori practice in from the margins, linguistically and conceptually, to a more central position within contemporary discourse. Further research is likely to shed more light on the relationship of these concepts to Montessori leadership. The connection of other aspects of Montessori philosophy to leadership, such as freedom, observation, beauty, and order, offer additional avenues for investigation. The connection of Dr. Montessori's ideas to leadership theorists who draw from ecological principles, holism, and systems theory could also be explored. Yet the centrality of the child, powered by inner constructive forces and beckoning the adult to follow, distinguishes her perspective. Her concept of the prepared environment contributes to a harmonious, century-old phronesis, offering a sustainable model of leadership that emphasizes human regeneration as the means to confront social problems. Underpinning her peaceful pedagogy is the release of potential through the free, independent development of individuals as the building blocks of society. This is an indirect preparation for leadership, offering potentially innovative and preventative avenues to approach contemporary issues in and beyond the classroom context.

While Dr. Montessori did not set out to write about leadership, she was a well-read leader of significance herself, and her references to leading are indicative of a strong and distinct position. Further study to articulate a Montessori perspective on leadership must therefore be seen as potentially fruitful for researchers and practitioners.

\section{Author Information}

\section{+ Corresponding Author}

Karen Bennettst is now an independent researcher in Mount Buller, Victoria, Australia. She can be reached at karenlbennetts@gmail.com.

Jane Bone is a senior lecturer in the Faculty of Education at Monash University.

\section{References}

Adair, J. E. (1989). Great leaders: Lessons from the world's greatest leaders. Talbot Adair Press.

Ahmed, Z., Nawaz, A., \& Khan, I. (2016). Leadership theories and styles: A literature review. Journal of Resources Development and Management, 16, 1-7. https://www.researchgate.net/ publication $/ 293885908$ Leadership_Theories and Styles A Literature Review.

Arvey, R., Dhanaraj, C., Javidan, M., \& Zhang, Z. X. (2015). Are there unique leadership models in Asia? Exploring unchartered territory. The Leadership Quarterly, 26(1), 1-6 https://doi.org/10.1016/j.leaqua.2015.01.003

Babini, V. P. (2000). Science, feminism and education: The early work of Maria Montessori. History Workshop Journal, 49(1), 44-67. https://doi.org/10.1093/hwj/2000.49.44

Bass, B. M., \& Riggio, R. E. (2006). Transformational leadership (2nd ed.). Lawrence Erlbaum Associates.

Bennetts, K., \& Bone, J. (2019). Adult leadership and the development of Children's Spirituality: Exploring Montessori's concept of the prepared environment. International Journal of Children's Spirituality, 24(4), 356-370. https://doi.org/10.1080/1364436X.2019.1685949

Blackmore, J. (2013). A feminist critical perspective on educational leadership. International Journal of Leadership in Education, 16(2), 139-154. https://doi.org/10.1080/13603124.2012.754057

Bone, J. (2019). Maria Montessori as domestic goddess: Iconic early childhood educator and material girl. Gender and Education, 31(6), 673-687. https://doi.org/10.1080/09540253.2017.1396293

Burns, J. M. (1978). Leadership. Harper \& Row.

Callahan, S. H. (2013). Religious leadership: A reference handbook. SAGE Publications. 
Conger, J. A. (1989). The charismatic leader: Behind the mystique of exceptional leadership. Jossey-Bass.

Cossentino, J. (2009). Culture, craft, \& coherence: The unexpected vitality of Montessori teacher training. Journal of Teacher Education, 60(5), 520-527. https://doi.org/10.1177/0022487109344593

Dempster, N., Lizzio, A., Keeffe, M., Skinner, J., \& Andrews, D. (2013). The contributions of research design and process facilitation in accessing adolescent views of leadership. Leading and Managing, 16(2), 77-89. https://repository.lboro.ac.uk/ndownloader/ files $/ 17086685 / 1$

Derungs, I. M. H. (2011). Trans-cultural leadership for transformation. Palgrave Macmillan.

Feez, S. (2007). Montessori's mediation of meaning: A social semiotic perspective [Doctoral dissertation, University of Sydney]. Sydney Digital Theses. http://hdl.handle.net/2123/1859

Feez, S. (2010). Montessori and early childhood: A guide for students. SAGE Publications.

Foschi, R. (2008). Science and culture around Montessori's first "Children's Houses" in Rome (1907-1915). Journal of the History of the Behavioural Sciences, 44(3), 238-257. https://doi.org/10.1002/jhbs.20313

Frierson, P. R. (2015). The virtue epistemology of Maria Montessori. Australasian Journal of Philosophy, 94(1). https://doi.org/10.1080/00048402.2015.1036895

Giacalone, R. A., \& Jurkiewicz, C. L. (Eds.). (2010). Handbook of workplace spirituality and organisational performance. M. E. Sharpe.

Gould, D., \& Voelker, D. K. (2012). Enhancing youth leadership through sport and physical education. The Journal of Physical Education, Recreation and Dance, 83(8), 38-41.

https://doi.org/10.1080/07303084.2012.10598828

Grazzini, C. (1997). Cosmic education at the elementary level and the role of the materials. The NAMTA Journal, 22(1), 40-63.

Greenleaf, R. K. (1977). Servant leadership: A journey into the nature of legitimate power and greatness. Paulist Press.

Gronn, P. (2010). Leadership: Its genealogy, configuration and trajectory. Journal of Educational Administration and History, 42(4), 405-435. https://doi.org/10.1080/00220620.2010.492959
Haines, A. (2001). Glossary of Montessori terms. Communications: Journal of the Association Montessori Internationale, 2-3, 51-59.

Heifetz, R. (2009). The practice of adaptive leadership: Tools and tactics for changing your organisation and the world. Harvard Business Press.

Helfrich, M. S. (2011). Montessori learning in the 21st century. New Sage Press.

Julien, M., Wright, B., \& McPhee, D. M. (2010). Stories from the circle: Leadership lessons learned from aboriginal leaders. Leadership Quarterly, 21(1), 114126. https://doi.org/0.1016/j.leaqua.2009.10.009

Kahn, D. (1981). Training, the teacher and praxis. The NAMTA Journal Quarterly, 6(3), 1-4.

Kahn, D. (2005). Project 2012: History whither bound from childhood to adolescence? The NAMTA Journal, 30(1), 140-153.

Kramer, R. (1988). Maria Montessori: A biography. Blackwell.

Lillard, A. S. (2005). Montessori: The science behind the genius. Oxford University Press.

Lloyd, K. (2008). An analysis of Maria Montessori's theory of normalization in light of emerging research in self-regulation [Doctoral dissertation, Oregon State University]. ScholarsArchive. https://search.library.oregonstate.edu/permalink/f/ ueodtl/CP71122306270001451

Montessori, M. (1964). The Montessori Method (A. E. George, Trans.). Schocken Books. (Original work published 1912)

Montessori, M. (1967). The discovery of the child (M. J. Costelloe, Trans.). Ballantine Books. (Original work published 1948)

Montessori, M. (1970). How it all happened: Summary of talk to students January 6, 1942, describing first Casa dei Bambini. Communications: Journal of the Association Montessori Internationale, 2/3, 2-7.

Montessori, M. (1989a). Education for a new world. Clio Press. (Original work published 1946)

Montessori, M. (1989b). To educate the human potential. Clio Press. (Original work published 1948)

Montessori, M. (1991). The advanced Montessori Method, Vol. 1 (F. Simmonds and L. Hutchinson, Trans.). Clio Press. (Original work published 1918)

Montessori, M. (1992). Education and peace (H. R. Lane, Trans.). Clio Press. (Original work published 1949) 
Montessori, M. (1994). From childhood to adolescence. Clio Press. (Original work published 1948)

Montessori, M. (2004). The creative development in the child: The Montessori approach, Vol. 1 (R. Ramachandran, Ed.; M. M. Montessori, Trans.). Kalakshetra Press. (Original work published 1994)

Montessori, M. (2007a). The absorbent mind (C. A. Claremont, Trans.). Montessori-Pierson. (Original work published 1949)

Montessori, M. (2012). The 1946 London lectures (A. Haines, Ed.). Montessori-Pierson.

Montessori, M. M., Jr. (1992). Education for human development: Understanding Montessori. MontessoriPierson.

Mooney, C. G. (2000). An introduction to Dewey, Montessori, Erikson, Piaget and Vygotsky. Redleaf Press.

Naumberg, M. (1913, December 13). Maria Montessori: Friend of children. The Outlook, 796-799. http://unz. org/Pub/Outlook-1913dec13-00796?View=PDF.

O'Donnell, M. (2013). Maria Montessori: A critical introduction to key themes and debates. Bloomsbury Academic.

Oxford University Press. (n.d.). Leadership. In Lexico.com dictionary. Retrieved August 17, 2020, from https://www.lexico.com/definition/leadership
Rhode, D. L. (Ed.). (2003). The difference "difference" makes: Women and leadership. Stanford University Press.

Schmidt, M., \& Schmidt, D. (2009). Understanding Montessori: A guide for parents. Dog Ear Publishing.

Standing, E. M. (1998). Maria Montessori: Her life and work. Plume. (Original work published 1957)

Tornar, C. (Ed.). (2001). Montessori bibliografia internazionale/International bibliography 1896-2000 (Dual language ed.). Edizioni Opera Nazionale Montessori.

Tourish, D. (2015). Some announcements, reaffirming the critical ethos of Leadership, and what we look for in submissions. Leadership, 11(2), 135-141. https://doi.org/10.1177/1742715015577889

Trabalzini, P. (2011). Maria Montessori through the seasons of the "Method." The NAMTA Journal, 36(2), i-218.

van Dierendonck, D. (2010). Servant leadership: A review and synthesis. Journal of Management, 37(4), $1228-1261$. https://doi.org/10.1177/0149206310380462 